\title{
High-Nuclearity Ruthenium Carbonyl Cluster Chemistry. 9. Ligand Substitution at Decaruthenium Carbonyl Clusters ${ }^{\S}$
}

Michael D. Randles, ${ }^{a}$ Marie P. Cifuentes, ${ }^{a}$ Graeme J. Moxey, ${ }^{a}$ Achim Zahl, ${ }^{b}$ Rudi van Eldik, ${ }^{* *}, \mathrm{~b}$ and Mark G. Humphrey ${ }^{*}$ a

${ }^{\text {a }}$ Research School of Chemistry, Australian National University, Canberra, ACT 2601, Australia

${ }^{\mathrm{b}}$ Department of Chemistry and Pharmacy, University of Erlangen-Nuremberg, Egerlandstr. 1, 91058 Erlangen, Germany

\begin{abstract}
The mono- to tri-substituted decaruthenium cluster anions $\left[\mathrm{Ru}_{10}(\mu-\mathrm{H})\left(\mu_{6}-\mathrm{C}\right)(\mathrm{CO})_{24-\mathrm{x}}(\mathrm{L})_{\mathrm{x}}\right]^{-}[\mathrm{L}=$ $\left.\mathrm{P}\left(\mathrm{C}_{6} \mathrm{H}_{4} \mathrm{Me}-4\right)_{3}, \mathrm{AsPh}_{3}, \mathrm{SbPh}_{3}, \mathrm{x}=1-3\right]$ were prepared as their $\left[\mathrm{PPh}_{4}\right]^{+}$salts in moderate to good yields from reaction of $\left[\mathrm{PPh}_{4}\right]\left[\mathrm{Ru}_{10}(\mu-\mathrm{H})\left(\mu_{6}-\mathrm{C}\right)(\mathrm{CO})_{24}\right]$ with the corresponding group 15 ligands at room temperature in acetone. The tetrakis-substituted cluster $\mathrm{Ru} 10\left(\mu_{6}-\mathrm{C}\right)\left(\mu_{3}-\mathrm{CO}\right)(\mu-\mathrm{CO})(\mathrm{CO})_{19}\left\{\mathrm{P}\left(\mathrm{C}_{6} \mathrm{H}_{4} \mathrm{Me}-\right.\right.$ 4) $\left.)_{3}\right\}_{4}$ was obtained in high yield from $\left[\mathrm{PPh}_{4}\right]_{2}\left[\mathrm{Ru}_{10}\left(\mu_{6}-\mathrm{C}\right)(\mathrm{CO})_{24}\right]$ and an excess of the phosphine under the same conditions; a single-crystal X-ray diffraction study revealed that the phosphines ligate at the vertices of the "giant tetrahedral" core. Kinetics studies of the formation of $\left[\mathrm{PPh}_{4}\right]\left[\mathrm{Ru}_{10}(\mu-\mathrm{H})\left(\mu_{6}\right.\right.$ $\left.\mathrm{C})\left(\mathrm{AsPh}_{3}\right)_{2}(\mathrm{CO})_{22}\right]$ from $\left[\mathrm{PPh}_{4}\right]\left[\mathrm{Ru}_{10}(\mu-\mathrm{H})\left(\mu_{6}-\mathrm{C}\right)\left(\mathrm{AsPh}_{3}\right)(\mathrm{CO})_{23}\right]$ shows that ligand substitution at these giant tetrahedral clusters proceeds via a strongly associative pathway with the likely intermediacy of a $\mathrm{Ru}-\mathrm{Ru}$ bond-cleaved intermediate.
\end{abstract}

Keywords: Ruthenium; High-nuclearity clusters; Kinetics; X-ray structure

\footnotetext{
* Corresponding author: E-mail: Mark.Humphrey@anu.edu.au.

** Present address: Faculty of Chemistry, Jagiellonian University, Ingardena 3, 30-060 Krakow, Poland.

$\S$ Dedicated to Professor Rick Adams on the occasion of his 70th birthday.
} 


\section{Introduction}

Low- and medium-nuclearity cluster chemistry $\left(M_{n}, n \leq 6\right)$ is well-developed, but considerably less is known of the chemistry of high-nuclearity clusters $\left(M_{n}, n>6\right)$, primarily due to the lack of facile highyielding routes into such species [1]. In our first foray into this field, we reported a straightforward route to the tetra-capped octahedral cluster anion $\left[\mathrm{Ru}_{10}(\mu-\mathrm{H})\left(\mu_{6}-\mathrm{C}\right)(\mathrm{CO})_{24}\right]^{-}$, obtained as its $\left[\mathrm{Ru}_{2}(\mu-\right.$ $\left.\left.\mathrm{NC}_{5} \mathrm{H}_{4}\right)_{2}(\mathrm{CO})_{4}\left(\mathrm{NC}_{5} \mathrm{H}_{5}\right)_{2}\right]^{+}$salt [2] in quantitative yield from heating $\mathrm{Ru}_{3}(\mu-\mathrm{H})\left(\mu-\mathrm{NC}_{5} \mathrm{H}_{4}\right)(\mathrm{CO})_{10}$ in refluxing chlorobenzene, and showed that, in contrast to expectations from prior studies of related decaosmium clusters $[3,4]$, the decaruthenium hydrido cluster anion exhibited molecular rather than bulk metallic behavior [5]. The reaction chemistry of $\left[\mathrm{Ru}_{10}(\mu-\mathrm{H})\left(\mu_{6}-\mathrm{C}\right)(\mathrm{CO})_{24}\right]^{-}$also contrasts starkly with the osmium system; the ruthenium cluster undergoes stepwise apical substitution of up to four carbonyl groups with triphenylphosphine or trimethylphosphite under very mild conditions [6-8], while the tetracapped octahedral osmium clusters require prior activation with halogens and reaction in refluxing xylene [9]. The first substitution takes place on the apical ruthenium bound to the hydride atom, with subsequent substitution occurring on the other apical ruthenium atoms.

Thus far, the substitution chemistry in the ruthenium system is restricted to these two ligands only at this specific hydrido cluster, and while ligand fluxionality has been explored [8], no studies probing the mechanism of substitution are extant. In continuation of our studies exploring high-nuclearity ruthenium cluster chemistry, we were interested in probing the nature of the ligand substitution mechanism at such clusters and in shedding light on the enormous disparity in reactivity between the ruthenium and osmium homologues. We report herein extension of ligand substitution at the hydrido cluster to embrace several other ligands, the first example of ligand substitution at the decaruthenium cluster dianion $\left[\mathrm{Ru}_{10}\left(\mu_{6-}\right.\right.$ $\left.\mathrm{C})(\mathrm{CO})_{24}\right]^{2-}$, the first X-ray structural study of a tetra-substituted decaruthenium cluster, and kinetic studies at one example aimed at affording insight into the mechanism of the substitution reactions.

\section{Results and discussion}

2.1. Syntheses and Spectroscopic Characterization. The precursor decaruthenium hydrido cluster anion $\left[\mathrm{Ru}{ }_{10}(\mu-\mathrm{H})\left(\mu_{6}-\mathrm{C}\right)(\mathrm{CO})_{24}\right]^{-}$and decaruthenium cluster dianion $\left[\mathrm{Ru}{ }_{10}\left(\mu_{6}-\mathrm{C}\right)(\mathrm{CO})_{24}\right]^{2-}$ are available as their $\left[\mathrm{PPh}_{4}\right]^{+}$salts in 45 and $8 \%$ yields, respectively [8], via thermolysis of the pyridyl-substituted triruthenium cluster $\mathrm{Ru}_{3}(\mu-\mathrm{H})\left(\mu-\mathrm{NC}_{5} \mathrm{H}_{4}\right)(\mathrm{CO})_{10}$ [10] in refluxing chlorobenzene in the presence of $\left[\mathrm{PPh}_{4}\right]\left[\mathrm{BF}_{4}\right]$, followed by separation using thin-layer chromatography (Scheme 1). While the yield of the dianion in particular is low, its hydrido pyridyl precursor $\mathrm{Ru}_{3}(\mu-\mathrm{H})\left(\mu-\mathrm{NC}_{5} \mathrm{H}_{4}\right)(\mathrm{CO})_{10}$ can be prepared on the gram scale, and thereby can afford sufficient of the decaruthenium clusters for subsequent study. 

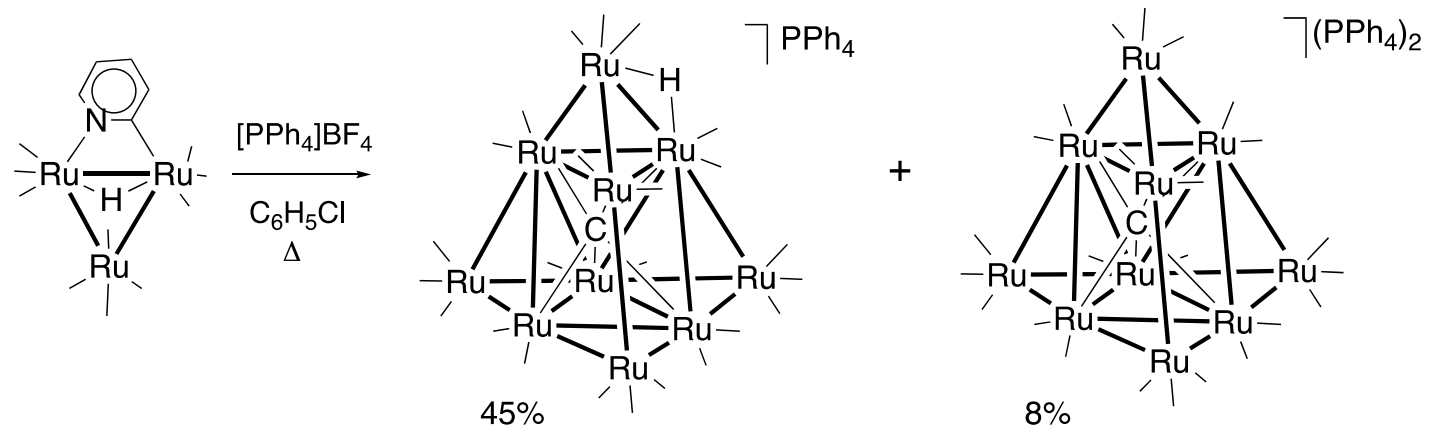

Scheme 1. Synthesis of the decaruthenium cluster anion $\left[\mathrm{PPh}_{4}\right]\left[\mathrm{Ru}{ }_{10}(\mu-\mathrm{H})\left(\mu_{6}-\mathrm{C}\right)(\mathrm{CO})_{24}\right]$ and dianion $\left[\mathrm{PPh}_{4}\right]_{2}\left[\mathrm{Ru} 10\left(\mu_{6}-\mathrm{C}\right)(\mathrm{CO})_{24}\right][8]$.

Ligand substitution of $\left[\mathrm{PPh}_{4}\right]\left[\mathrm{Ru}_{10}(\mu-\mathrm{H})\left(\mu_{6}-\mathrm{C}\right)(\mathrm{CO})_{24}\right]$ by several two-electron ligands of varying nucleophilicity and cone angle, namely $\mathrm{P}_{(}\left(\mathrm{C}_{6} \mathrm{H}_{4} \mathrm{Me}-4\right)_{3}, \mathrm{AsPh}_{3}$ and $\mathrm{SbPh}_{3}$, was then probed (Scheme 2). The mono-substituted derivatives [PPh $]\left[\mathrm{Ru}_{10}(\mu-\mathrm{H})\left(\mu_{6}-\mathrm{C}\right)(\mathrm{CO})_{23}(\mathrm{~L})\right]\left[\mathrm{L}=\mathrm{P}\left(\mathrm{C}_{6} \mathrm{H}_{4} \mathrm{Me}-4\right)_{3} \mathbf{1 a}, \mathrm{AsPh}_{3} \mathbf{1 b}\right.$, $\left.\mathrm{SbPh}_{3} \mathbf{1 c}\right]$ were obtained by adding approximately one equivalent of reactant to a stirred solution of $\left[\mathrm{PPh}_{4}\right]\left[\mathrm{Ru}_{10}(\mu-\mathrm{H})\left(\mu_{6}-\mathrm{C}\right)(\mathrm{CO})_{24}\right]$ in acetone at room temperature. IR spectra of the reaction mixtures immediately following addition showed complete conversion of the starting material, and subsequent workup afforded the mono-substituted complexes in high to moderate yields (82, 77 and $56 \%$, respectively). Similar reactions using 2-3 equivalents of reactant (over $2 \mathrm{~h}$ in the case of $\mathrm{P}\left(\mathrm{C}_{6} \mathrm{H}_{4} \mathrm{Me}-4\right)$ or $72 \mathrm{~h}$ for $\mathrm{AsPh}_{3}$ and $\left.\mathrm{SbPh}_{3}\right)$ afforded mixtures of the bis- and tris-substituted derivatives $\left[\mathrm{PPh}_{4}\right]\left[\mathrm{Ru}_{10}(\mu\right.$ $\left.\mathrm{H})\left(\mu_{6}-\mathrm{C}\right)(\mathrm{CO})_{22}(\mathrm{~L})_{2}\right]\left[\mathrm{L}=\mathrm{P}\left(\mathrm{C}_{6} \mathrm{H}_{4} \mathrm{Me}-4\right)_{3} \mathbf{2 a}, \mathrm{AsPh}_{3} \mathbf{2 b}, \mathrm{SbPh}_{3}\right.$ 2c $]$ and $\quad\left[\mathrm{PPh}_{4}\right]\left[\mathrm{Ru} 10(\mu-\mathrm{H})\left(\mu_{6}-\right.\right.$ $\left.\mathrm{C})(\mathrm{CO})_{21}(\mathrm{~L})_{3}\right]\left[\mathrm{L}=\mathrm{P}\left(\mathrm{C}_{6} \mathrm{H}_{4} \mathrm{Me}-4\right)_{3} \mathbf{3 a}, \mathrm{AsPh}_{3} \mathbf{3 b}, \mathrm{SbPh}_{3} \mathbf{3 c}\right]$ in moderate to low yields. No evidence was found for the presence of the tetrakis-substituted complexes $\left[\mathrm{PPh}_{4}\right]\left[\mathrm{Ru}_{10}(\mu-\mathrm{H})\left(\mu_{6}-\mathrm{C}\right)(\mathrm{CO})_{20}(\mathrm{~L})_{4}\right][\mathrm{L}=$ $\left.\mathrm{P}\left(\mathrm{C}_{6} \mathrm{H}_{4} \mathrm{Me}-4\right)_{3}, \mathrm{AsPh}_{3}, \mathrm{SbPh}_{3}\right)$, although the triphenylphosphine and trimethylphosphite analogues $\left[\mathrm{PPh}_{4}\right]\left[\mathrm{Ru}_{10}(\mu-\mathrm{H})\left(\mu_{6}-\mathrm{C}\right)(\mathrm{CO})_{20}\left(\mathrm{PR}_{3}\right)_{4}\right](\mathrm{R}=\mathrm{Ph}[8], \mathrm{OMe}[7])$ have been reported as a trace component and in $14 \%$ yield, respectively, from analogous reactions. The extent of substitution, yields and reaction times are therefore consistent with the reactivity series $\mathrm{P}(\mathrm{OMe})_{3}>\mathrm{PPh}_{3}, \mathrm{P}\left(\mathrm{C}_{6} \mathrm{H}_{4} \mathrm{Me}-4\right)_{3}>\mathrm{AsPh}_{3}>\mathrm{SbPh}_{3}$. Carbonyl substitution at the dianionic cluster $\left[\mathrm{Ru} 10\left(\mu_{6}-\mathrm{C}\right)(\mathrm{CO})_{24}\right]^{2-}$ is thus far unexplored, so has also been pursued in the present studies. In contrast to the mono-anionic hydrido cluster, attempts to synthesize mono-, bis- and tris-substituted products from $\left[\mathrm{PPh}_{4}\right]_{2}\left[\mathrm{Ru}{ }_{10}\left(\mu_{6}-\mathrm{C}\right)(\mathrm{CO})_{24}\right]$ proved unsuccessful, one to several equivalents of phosphine resulting in no reaction. However, with a large excess of phosphine (at least ten-fold), reaction occurred almost instantaneously following addition, but only the tetra-substituted neutral cluster $\mathrm{Ru}_{10}\left(\mu_{6}-\mathrm{C}\right)\left(\mu_{3}-\mathrm{CO}\right)(\mu-\mathrm{CO})(\mathrm{CO})_{19}\left\{\mathrm{P}\left(\mathrm{C}_{6} \mathrm{H}_{4} \mathrm{Me}_{-} 4\right)_{3}\right\}_{4}$ (4a) was obtained in which the formerly dianionic charge is compensated by an additional $2 \mathrm{e}$ donor ligand (Scheme 3$)$. Overall, $\left[\mathrm{Ru} \mathrm{u}_{10}\left(\mu_{6-}\right.\right.$ $\left.\mathrm{C})(\mathrm{CO})_{24}\right]^{2-}$ has undergone two-electron oxidation in yielding the neutral cluster $4 \mathbf{a}$. An osmium analogue 
$\mathrm{Os}_{10}\left(\mu_{6}-\mathrm{C}\right)(\mathrm{CO})_{21}\left\{\mathrm{P}(\mathrm{OMe})_{3}\right\}_{4}$ exists, synthesized from $\mathrm{Os}_{10} \mathrm{H}_{2}\left(\mu_{6}-\mathrm{C}\right)(\mathrm{CO})_{24}$ and excess $\mathrm{P}(\mathrm{OMe})_{3}$ under the considerably more forcing conditions of refluxing xylene [9].

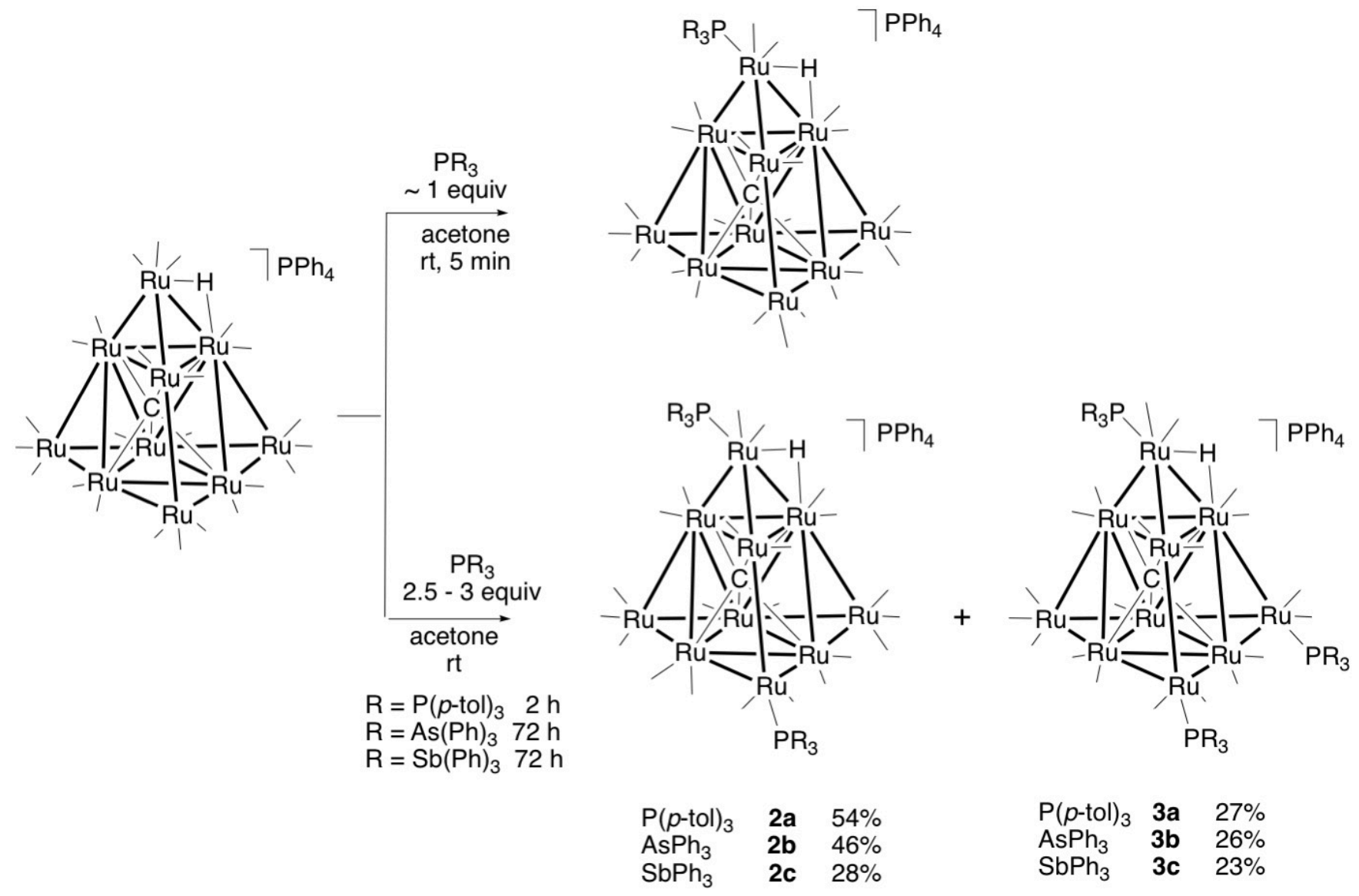

Scheme 2. Preparation of decaruthenium cluster anions $\left[\mathrm{Ru}_{10}\left(\mu_{6}-\mathrm{C}\right)(\mathrm{CO})_{24-\mathrm{x}}(\mathrm{L})_{\mathrm{x}}\right]^{-}\left[\mathrm{L}=\mathrm{P}\left(\mathrm{C}_{6} \mathrm{H}_{4} \mathrm{Me}-4\right)_{3}\right.$, $\left.\mathrm{AsPh}_{3}, \mathrm{SbPh}_{3} ; \mathrm{x}=1-3\right]$.
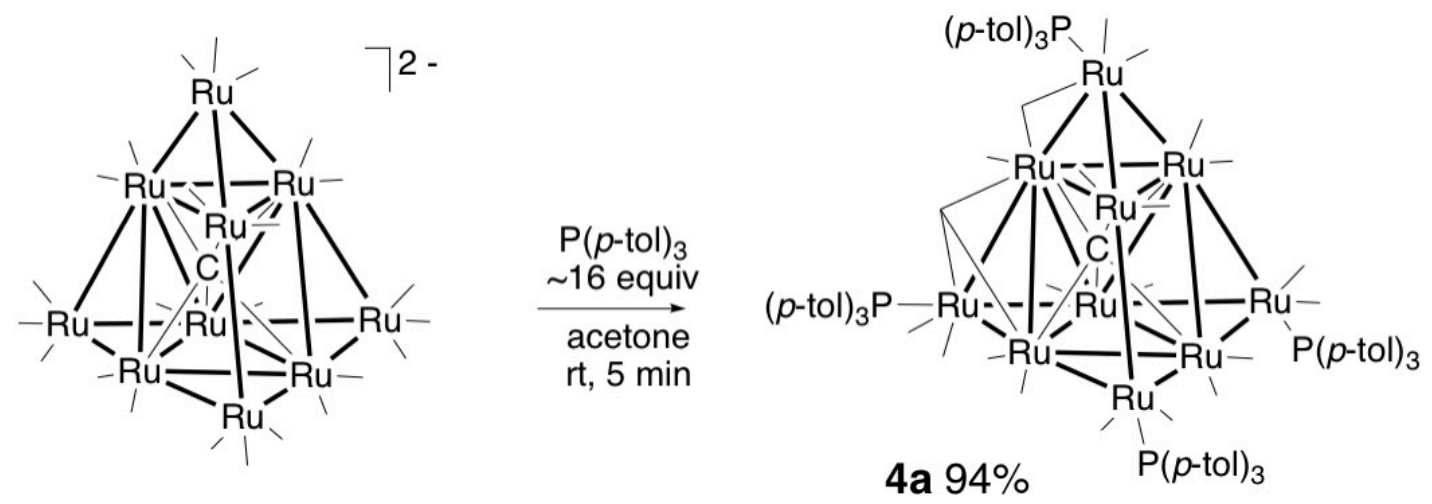

Scheme 3. Preparation of $\mathrm{Ru}_{10}\left(\mu_{6}-\mathrm{C}\right)\left(\mu_{3}-\mathrm{CO}\right)(\mu-\mathrm{CO})(\mathrm{CO})_{19}\left(\mathrm{P}\left\{\mathrm{C}_{6} \mathrm{H}_{4} \mathrm{Me}-4\right)_{3}\right\}_{4}(\mathbf{4 a})$.

The new ligand-substituted clusters were characterized by a combination of solution IR, ${ }^{1} \mathrm{H}-\mathrm{NMR}$ and ${ }^{31}$ P-NMR spectroscopies, ESI mass spectrometry, and satisfactory elemental microanalyses; key spectral data are collected in Table 1. The solution IR spectra for each set of compounds show a characteristic 
pattern that is dependent on the extent of substitution. In the mono-substituted complexes 1a-c, four v(CO) bands are observed corresponding to terminally bound CO ligands $\left(2078-1999 \mathrm{~cm}^{-1}\right)$, with only minor shifts (up to $4 \mathrm{~cm}^{-1}$ ) between the most electron-withdrawing and -donating ligands. Similarly, the IR spectra for the bis-substituted examples 2a-c contain five bands due to terminal CO ligands (2066 - 1990 $\mathrm{cm}^{-1}$ ), while the tris-substituted series 3a-c show three carbonyl stretching bands $\left(2051-1997 \mathrm{~cm}^{-1}\right)$. The proton NMR spectra contain a characteristic signal due to the bridging hydride ligand between -11.53 and $-12.36 \mathrm{ppm}$. The hydride resonances are shifted upfield on moving from co-ligand $\mathrm{P}\left(\mathrm{C}_{6} \mathrm{H}_{4} \mathrm{Me}-4\right)_{3}$ to $\mathrm{AsPh}_{3}$ and then $\mathrm{SbPh}_{3}$, and occur as a doublet (with coupling of around $7 \mathrm{~Hz}$ ) for each of the phosphine adducts (1a-3a), consistent with the hydride being located in close proximity to the phosphine ligand. The ${ }^{31} \mathrm{P}-\mathrm{NMR}$ spectrum for each of the anionic clusters shows a signal at $24.0 \mathrm{ppm}$ due to the $\mathrm{PPh}_{4}$ counterion. In addition, the phosphine-substituted examples 1a-3a contain a resonance corresponding to the phosphine ligand adjacent to the hydride (in the range 42.0-39.4 ppm), the signal moving slightly upfield as the cluster becomes more electron rich on moving from the mono- through to the tris-substituted example. A second resonance is observed in the bis- and tris-substituted clusters (49.8 ppm for $\mathbf{2 a}$ and $47.6 \mathrm{ppm}$ for 3a), with the signals occurring in a 1:1 ratio against the hydride-adjacent phosphine ligand for $\mathbf{2 a}$, and $2: 1$ for $\mathbf{3 a}$. The IR spectrum of the tetrakis(phosphine)-substituted cluster $\operatorname{Ru} 10\left(\mu_{6}-\mathrm{C}\right)\left(\mu_{3}-\right.$

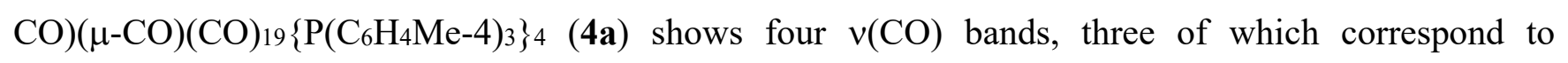
terminally-bound carbonyls $\left(2042-1985 \mathrm{~cm}^{-1}\right)$, while the other band is in the bridging carbonyl region $\left(1714 \mathrm{~cm}^{-1}\right)$. The ${ }^{31} \mathrm{P}-\mathrm{NMR}$ spectrum contains a single resonance at $44.5 \mathrm{ppm}$ corresponding to the four phosphine ligands, due to the symmetry of the core and presumed fluxionality of the carbonyl ligands. Intense molecular anion peaks, containing the theoretically predicted isotope patterns, are seen in the ESI mass spectra for all anionic cluster examples, while a sodium adduct of the molecular ion is seen in the ESI mass spectrum of $\mathbf{4 a}$. 
Table 1. Key spectral data for $\left[\mathrm{PPh}_{4}\right]\left[\mathrm{Ru}_{10}(\mu-\mathrm{H})\left(\mu_{6-\mathrm{C}}\right)(\mathrm{CO})_{24-\mathrm{x}}(\mathrm{L})_{\mathrm{x}}\right]$.

\begin{tabular}{|c|c|c|c|c|c|}
\hline & $\mathrm{L}$ & & $\mathrm{IR}^{\mathrm{a}} v(\mathrm{CO})$ & $\delta^{1} \mathrm{HNMR}^{\mathrm{b}}$ & $\delta^{31} \mathrm{P} \mathrm{NMR}^{\mathrm{b}}$ \\
\hline \multirow[t]{3}{*}{$x=1$} & $\mathrm{P}\left(\mathrm{C}_{6} \mathrm{H}_{4} \mathrm{Me}-4\right)_{3}$ & $1 \mathbf{a}$ & 2076w, 2046vs, 2017s, 2001s & $-11.53\left(\mathrm{~d}, J_{\mathrm{PH}}=7.2 \mathrm{~Hz}\right)$ & $42.0,24.0(1: 1)$ \\
\hline & $\mathrm{AsPh}_{3}$ & $1 \mathbf{b}$ & $2078 \mathrm{w}, 2048 \mathrm{vs}, 2017 \mathrm{~s}, 2002 \mathrm{~s}$ & -11.81 & 24.0 \\
\hline & $\mathrm{SbPh}_{3}$ & $1 \mathrm{c}$ & $2078 \mathrm{w}, 2048 \mathrm{vs}, 2016 \mathrm{~s}, 2003 \mathrm{~s}$ & -12.36 & 24.0 \\
\hline \multirow[t]{3}{*}{$x=2$} & $\mathrm{P}\left(\mathrm{C}_{6} \mathrm{H}_{4} \mathrm{Me}-4\right)_{3}$ & $2 a$ & $\begin{array}{l}2062 \mathrm{w}, 2038 \mathrm{~s}, 2011 \mathrm{~s}, \mathrm{sh}, \\
2007 \mathrm{vs}, 1991 \mathrm{~m}, \mathrm{sh}\end{array}$ & $-11.49\left(\mathrm{~d}, J_{\mathrm{PH}}=7.2 \mathrm{~Hz}\right)$ & $49.8,41.0,24.0(1: 1: 1)$ \\
\hline & $\mathrm{AsPh}_{3}$ & $2 \mathbf{b}$ & $\begin{array}{l}2065 \mathrm{w}, 2041 \mathrm{~s}, 2012 \mathrm{~s}, \mathrm{sh}, \\
2008 \mathrm{vs}, 1993 \mathrm{~m}, \mathrm{sh}\end{array}$ & -11.71 & 24.0 \\
\hline & $\mathrm{SbPh}_{3}$ & $2 c$ & $\begin{array}{l}\text { 2066w, 2042s, 2011s, sh, } \\
2007 \mathrm{vs}, 1993 \mathrm{~m}, \mathrm{sh}\end{array}$ & -12.26 & 24.0 \\
\hline \multirow[t]{3}{*}{$x=3$} & $\mathrm{P}\left(\mathrm{C}_{6} \mathrm{H}_{4} \mathrm{Me}-4\right)_{3}$ & $\mathbf{3 a}$ & 2046w, 2011m, 1998vs & $-11.57\left(\mathrm{~d}, J_{\mathrm{PH}}=7.2 \mathrm{~Hz}\right)$ & $47.6,39.4,24.0(2: 1: 1)$ \\
\hline & $\mathrm{AsPh}_{3}$ & $\mathbf{3 b}$ & 2050w, 2013m, 2000vs & -11.68 & 24.0 \\
\hline & $\mathrm{SbPh}_{3}$ & $3 c$ & $2051 \mathrm{w}, 2013 \mathrm{~m}, 2000 \mathrm{vs}$ & -12.21 & 24.0 \\
\hline
\end{tabular}

a) acetone, $\mathrm{cm}^{-1}$; b) $\mathrm{d}_{6}$-acetone, ppm.

2.2. X-ray Structural Study of $\mathbf{4 a}$. A single-crystal X-ray diffraction study of $\mathbf{4 a}$ was carried out, confirming its molecular composition. Figure 1 shows an ORTEP plot with the molecular structure and atomic labeling schemes together with the key bond length parameters. The metal core maintains the tetracapped octahedral geometry of the parent compound, with a $\mu_{6}$-carbide located in the center of the octahedron. The structure also contains nineteen terminally bound, one edge bridging and one facecapping carbonyl ligands. The edge-bridging carbonyl is formally semi-bridging, with an asymmetry

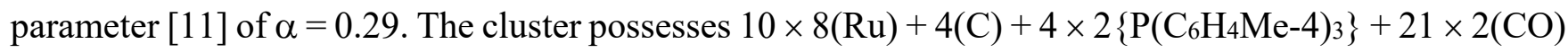
$=134 \mathrm{CVE}$, which is the expected count using the "condensation principle" for an octahedron and four tetrahedra. The $\mathrm{Ru}-\mathrm{Ru}$ bonds of the octahedral cavity are in the range $2.8289-2.9453 \AA$, with a mean distance of $2.870 \pm 0.002 \AA\left(c . f .2 .86 \pm 0.002 \AA\right.$ for $\left.\left[\mathrm{Ru} 10(\mu-\mathrm{H})\left(\mu_{6}-\mathrm{C}\right)(\mathrm{CO})_{24}\right]^{-}\right)$. The $\mathrm{Ru}-\mathrm{Ru}$ bonds external to the octahedral carbido cavity are in the range $2.7351-2.9714 \AA$, with a mean distance significantly longer than that in $\left[\mathrm{Ru}_{10}(\mu-\mathrm{H})\left(\mu_{6}-\mathrm{C}\right)(\mathrm{CO})_{24}\right]^{-}(2.838 \pm 0.002 \AA$ c.f. $2.770 \pm 0.002 \AA)$. Thus, there is a small core expansion seen on replacing $(3 \mathrm{CO}+2 \mathrm{e})$ with $4\left[\mathrm{P}\left(\mathrm{C}_{6} \mathrm{H}_{4} \mathrm{Me}-4\right)_{3}\right]$. 

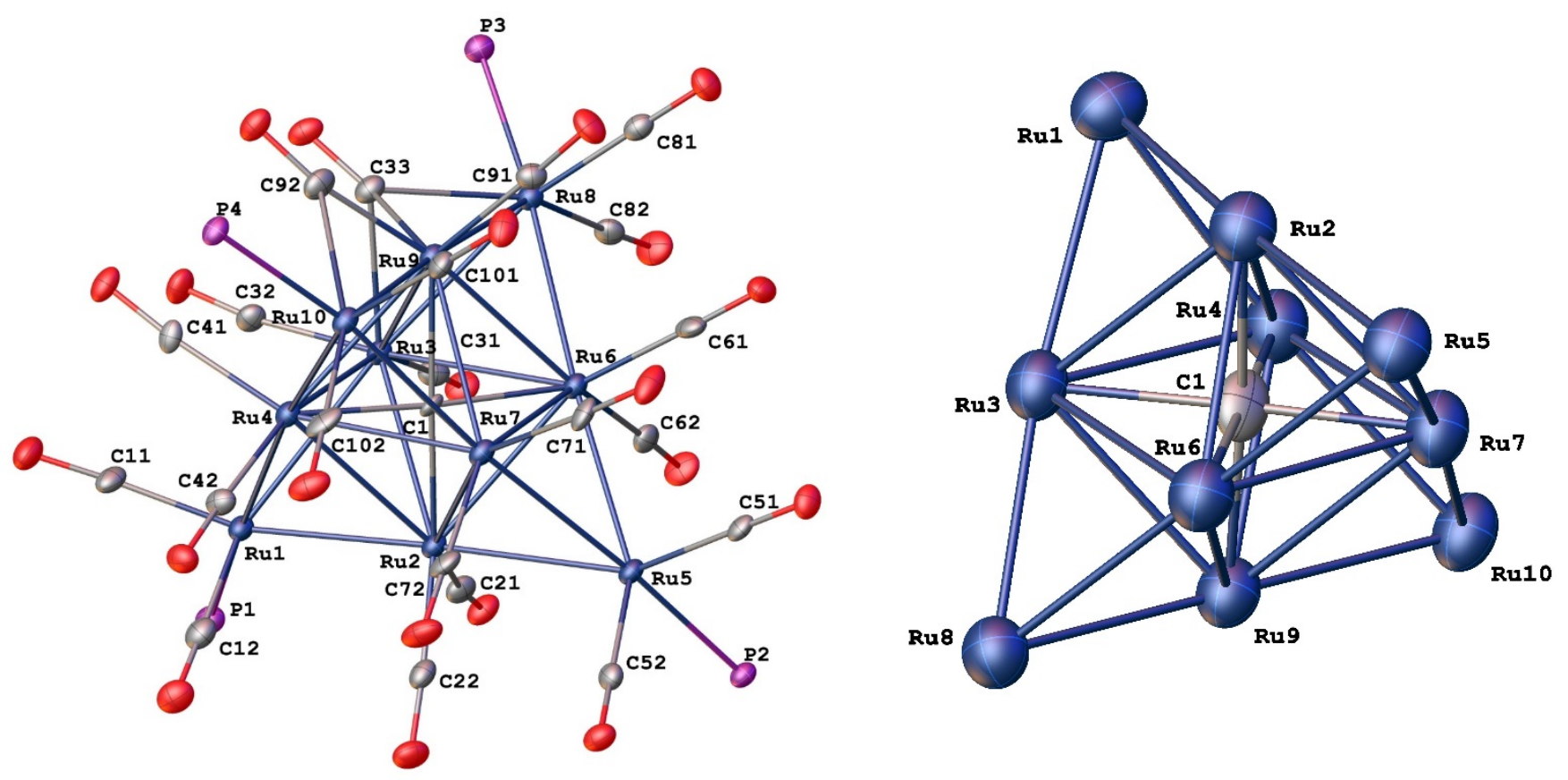

Figure 1. Left: Molecular structure of $\mathrm{Ru}_{10}\left(\mu_{6}-\mathrm{C}\right)\left(\mu_{3}-\mathrm{CO}\right)(\mu-\mathrm{CO})(\mathrm{CO})_{19}\left(\mathrm{P}\left\{\mathrm{C}_{6} \mathrm{H}_{4} \mathrm{Me}-4\right)_{3}\right\}_{4}$ (4a), with thermal ellipsoids set at the $40 \%$ probability level. Phosphine ligand substituents have been omitted for clarity. Right: The tetra-capped octahedral metal core of $\mathbf{4 a}$, with $40 \%$ thermal ellipsoids. Selected bond lengths (Å): Ru—Ru bonds: Ru1-Ru2 2.7351(11), Ru1-Ru3 2.9714(12), Ru1-Ru4 2.8296(11), Ru2-Ru3 2.8793(11), Ru2-Ru4 2.9453(10), Ru2-Ru5 2.8574(11), Ru2-Ru6 2.8289(12), Ru2-Ru7 2.8577(11), Ru3Ru4 2.8662(10), Ru3-Ru6 2.8850(10), Ru3-Ru8 2.8673(12), Ru3-Ru9 2.8649(10), Ru4-Ru7 2.8565(11), Ru4-Ru9 2.8380(12), Ru4-Ru10 2.8276(11), Ru5-Ru6 2.7657(11), Ru5-Ru7 2.8905(10), Ru6-Ru7 2.8519(11), Ru6-Ru8 2.8084(11), Ru6-Ru9 2.8658(10), Ru7-Ru9 2.9078(11), Ru7-Ru10 2.8312(10), Ru8Ru9 2.8660(11), Ru9-Ru10 2.8118(11). Interstitial carbide: Ru2-C1 2.005(8), Ru3-C1 2.079(8), Ru4-C1 2.012(8), Ru6-C1 2.030(8), Ru7-C1 1.984(8), Ru9-C1 2.073(8). Bridging ligands: Ru3-C33 2.285(11), Ru8-C33 2.238(11), Ru9-C33 2.123(11), Ru9-C92 1.936(12), Ru10-C92 2.479(11).

2.3. Kinetics of Ligand Substitution. A study of the kinetics of ligand substitution under pseudo-firstorder conditions requires use of a large excess of the incoming ligand. In order to determine the most suitable candidate for kinetic studies of ligand substitution at $\left[\mathrm{Ru} 10(\mu-\mathrm{H})\left(\mu_{6}-\mathrm{C}\right)(\mathrm{CO})_{24}\right]^{-}$, approximately ten equivalents of a range of tertiary phosphines and phosphites $\left[\mathrm{P}(\mathrm{OEt})_{3}, \mathrm{P}(\mathrm{OPh})_{3}, \mathrm{PMe}_{3}, \mathrm{P}\left(\mathrm{C}_{6} \mathrm{H}_{4} \mathrm{OEt}-\right.\right.$ 4) $)_{3}, \mathrm{P}\left(\mathrm{C}_{6} \mathrm{H}_{4} \mathrm{Me}-4\right)_{3}, \mathrm{P}\left(\mathrm{C}_{6} \mathrm{H}_{2} \mathrm{Me}_{2}-3,5-\mathrm{OMe}-4\right)_{3}$ and $\left.\mathrm{P}\left(\mathrm{C}_{6} \mathrm{~F}_{5}\right)_{3}\right]$ were added to stirred solutions of the cluster $\left[\mathrm{PPh}_{4}\right]\left[\mathrm{Ru}_{10}(\mu-\mathrm{H})\left(\mu_{6}-\mathrm{C}\right)(\mathrm{CO})_{24}\right]$ in acetone at room temperature. Excluding $\mathrm{P}\left(\mathrm{C}_{6} \mathrm{~F}_{5}\right)_{3}$, which failed to react at all, each of the phosphines tested reacted too quickly to be useful in mechanistic studies, so these were not pursued further. $\mathrm{AsPh}_{3}$ and $\mathrm{SbPh}_{3}$ were tested in the same way, and in contrast to the phosphines they were found to react sufficiently slowly to allow detailed kinetic studies. While $\mathrm{AsPh}_{3}$ and $\mathrm{SbPh}_{3}$ slowed the reaction down significantly, a kinetic trace of the transformation from the unsubstituted cluster to the 
mono-substituted cluster could still not be obtained since this step is too fast; hence, the transformation from $\left[\mathrm{PPh}_{4}\right]\left[\mathrm{Ru}_{10}(\mu-\mathrm{H})\left(\mu_{6}-\mathrm{C}\right)\left(\mathrm{AsPh}_{3}\right)(\mathrm{CO})_{23}\right](\mathbf{1 b})$ to $\left[\mathrm{PPh}_{4}\right]\left[\mathrm{Ru}_{10}(\mu-\mathrm{H})\left(\mu_{6}-\mathrm{C}\right)\left(\mathrm{AsPh}_{3}\right)_{2}(\mathrm{CO})_{22}\right](\mathbf{2 b})$ was studied, since the reaction progression could be monitored over a convenient time scale for the disappearance of the hydride signal corresponding to $\mathbf{1 b}$ and the appearance of resonances for $\mathbf{2 b}$ and then $\left[\mathrm{PPh}_{4}\right]\left[\mathrm{Ru}_{10}(\mu-\mathrm{H})\left(\mu_{6}-\mathrm{C}\right)\left(\mathrm{AsPh}_{3}\right)_{3}(\mathrm{CO})_{21}\right](\mathbf{3 b})$ (Figure 2).

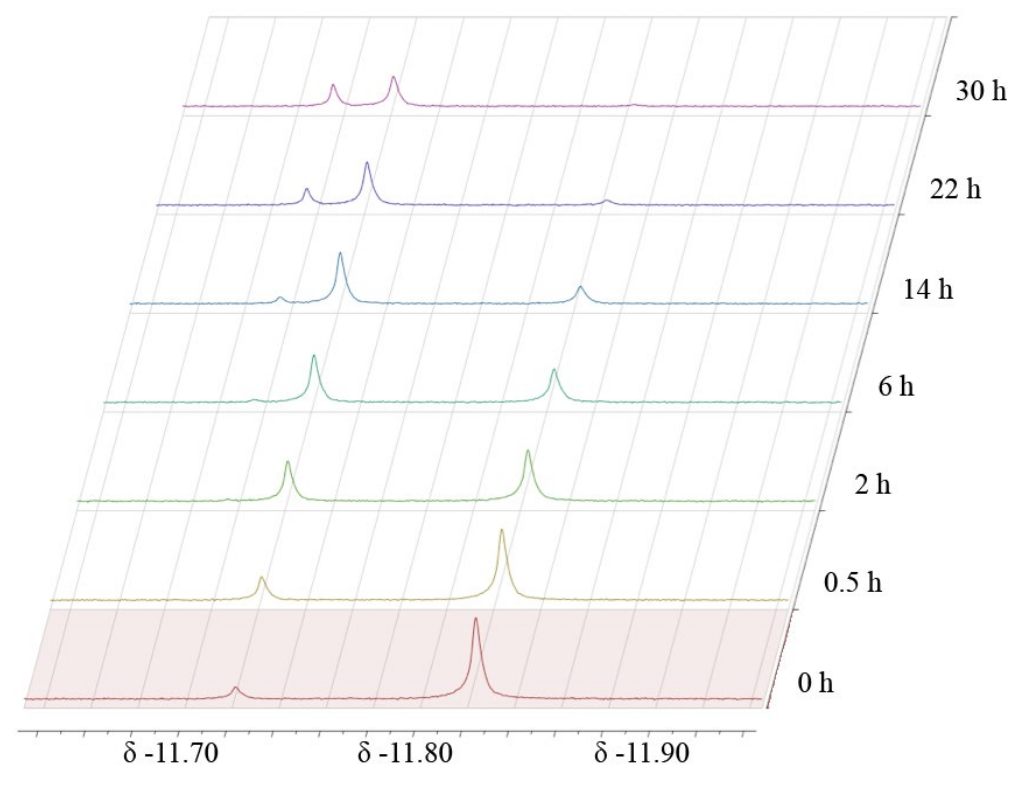

Figure 2. Plot of the hydride region of the ${ }^{1} \mathrm{H}$ NMR spectra as a function of time. Left to right, the resonances correspond to $\mathbf{3 b}, \mathbf{2} \mathbf{b}$ and $\mathbf{1 b}$.

By keeping both the temperature and pressure constant under pseudo-first-order conditions, the observed rate of the reaction could be determined by monitoring the disappearance of the hydride signal of $\mathbf{1 b}$ over time, as $\mathbf{2} \mathbf{b}$ is formed. The exponential decay observed for the disappearance of $\mathbf{1 b}$ fits to a single exponential equation, thereby affording the observed rate constant for a specific concentration. By varying the concentration of the ligand while maintaining pseudo-first-order reaction conditions, a concentration dependence curve for the formation of $\mathbf{2 b}$ was constructed. Plotting the observed rate constant versus the ligand concentration revealed a linear relationship with an $\mathrm{x}$-intercept of zero $\pm 3 \%$ (Figure 3, left). Consequently, any back reaction could be ignored from our calculations and a rate constant for the formation of $\mathbf{2 b}$ was obtained as $(4.2 \pm 0.2) \times 10^{-4} \mathrm{M}^{-1} \mathrm{~s}^{-1}$. The entropy and enthalpy of activation for the reaction were determined by varying the temperature of the reaction while keeping both the pressure and ligand concentration constant; a temperature dependence curve was constructed by plotting $\ln (k / \mathrm{T})$ vs $1 / \mathrm{T}$ (Figure 3, right), which produced a linear relationship, affording values of $\Delta H^{\ddagger}$ and $\Delta \mathrm{S}^{\neq}$as $27.6 \pm 0.8 \mathrm{~kJ} \mathrm{~mol}^{-1}$ and $-217 \pm 3 \mathrm{~J} \mathrm{~mol}^{-1} \mathrm{~K}^{-1}$, respectively. 

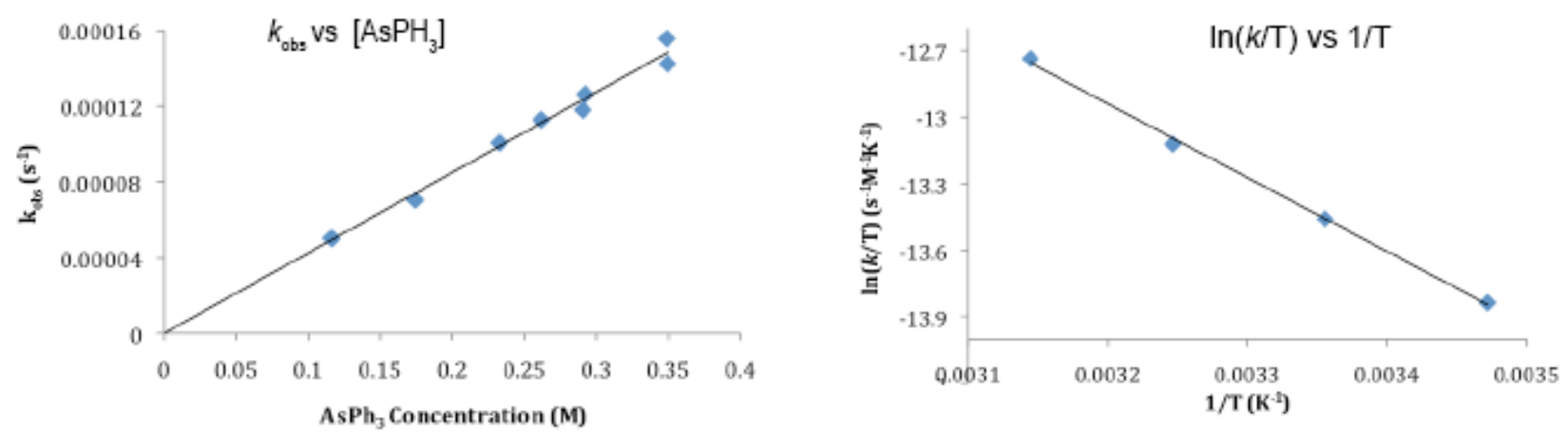

Figure 3. Left: Concentration dependence of $k_{\text {obs }}$ for reaction of $\left[\mathrm{PPh}_{4}\right]\left[\mathrm{Ru}_{10}(\mu-\mathrm{H})\left(\mu_{6}-\mathrm{C}\right)\left(\mathrm{AsPh}_{3}\right)(\mathrm{CO})_{23}\right]$ (1b) with $\mathrm{AsPh}_{3}$ at $298 \mathrm{~K}$ and $0.1 \mathrm{MPa}$. Right: Temperature dependence plot, $\left[\mathrm{AsPh}_{3}\right]=0.116 \mathrm{M}, \mathrm{P}=0.1$ $\mathrm{MPa}$.

Table 2. $\Delta H^{\ddagger}$ and $\Delta \mathrm{S}^{\neq}$values for associative ligand substitution at some selected ruthenium and osmium clusters.

\begin{tabular}{lllll}
\hline Cluster & Ligand & $\Delta H^{\ddagger}\left(\mathrm{kJ} \mathrm{mol}^{-1}\right)$ & $\Delta \mathrm{S}^{\neq}\left(\mathrm{J} \mathrm{mol}^{-1} \mathrm{~K}^{-1}\right)$ & Reference \\
\hline $\mathrm{Ru}_{3}(\mathrm{CO})_{12}{ }^{\mathrm{a}}$ & $\mathrm{PPh}_{3}$ & $64.6 \pm 0.6$ & $-102 \pm 2$ & {$[12]$} \\
& $\mathrm{AsPh}_{3}$ & $51 \pm 14$ & $-147 \pm 43$ & \\
$\mathrm{Os}_{3}(\mu-\mathrm{H})_{2}(\mathrm{CO})_{10^{b}} \mathrm{~b}$ & $\mathrm{PPh}_{3}$ & $96.49 \pm 4.77$ & $-1.71 \pm 14.78$ & {$[13]$} \\
$\operatorname{Ru}_{5}\left(\mu_{5}-\mathrm{C}\right)(\mathrm{CO})_{15^{\mathrm{b}}} \mathrm{b}$ & $\mathrm{PPh}_{3}$ & $33.53 \pm 2.85$ & $-91.7 \pm 9.6$ & {$[14]$} \\
$\mathrm{Ru}_{6}\left(\mu_{6}-\mathrm{C}\right)(\mathrm{CO})_{17^{\mathrm{b}}}$ & $\mathrm{PPh}_{3}$ & $31.5 \pm 0.4$ & $-161.2 \pm 1.2$ & {$[15]$} \\
$\mathbf{1 a}^{\mathrm{c}}$ & $\mathrm{AsPh}_{3}$ & $27.6 \pm 0.8$ & $-217 \pm 3$ & Present work \\
\hline
\end{tabular}

a) decalin; b) heptane; c) acetone.

Kinetic data for selected group 8 metal carbonyl clusters are shown in Table 2 . The limited data suggest that $\Delta H^{\ddagger}$ and $\Delta \mathrm{S}^{\ddagger}$ values decrease with increasing cluster nuclearity and proceeding from Os to $\mathrm{Ru}$. Keeping both the temperature and ligand concentration constant afforded a pressure-dependence curve of $\ln (k)$ versus $\mathbf{P}$ for the formation of $\mathbf{2 b}$ from $\mathbf{1 b}$ (Figure 4), giving $\Delta V^{\ddagger}=-36 \pm 3 \mathrm{~cm}^{3} \mathrm{~mol}^{-1}$. This value for $\Delta V^{\ddagger}$ suggests that the addition of ligand to the cluster must occur via a strongly associative mechanistic pathway, which is in line with the very negative activation entropy value found for this reaction. The related osmium cluster $\left[\mathrm{Os} 10\left(\mu_{6}-\mathrm{C}\right)(\mathrm{CO})_{24}\right]^{2-}$ is "remarkably resistant to nucleophiles", requiring Os-Os cleavage by halogens and harsh reaction conditions. Similarly, $\left[\mathrm{Os}_{10}\left(\mu_{6}-\mathrm{C}\right)(\mathrm{CO})_{24}(\mu-\mathrm{I})_{2}\right]$ does not react 
with excess $\mathrm{P}(\mathrm{OMe})_{3}$ in refluxing toluene over prolonged periods, but needs heating in refluxing xylene over $4 \mathrm{~h}$ [9]. In general, 5d metal complexes are kinetically inert compared to their $4 \mathrm{~d}$ metal complex homologues, and Os-Os bonds in clusters are considerably stronger than analogous Ru-Ru bonds. The results from the present study and the strongly contrasting reactivity between the osmium and ruthenium systems suggest that ligand substitution in these large clusters proceeds via an associative intermediate that involves the cleavage of a metal-metal bond, a plausible intermediate species as it would maintain the overall electron count of the cluster.

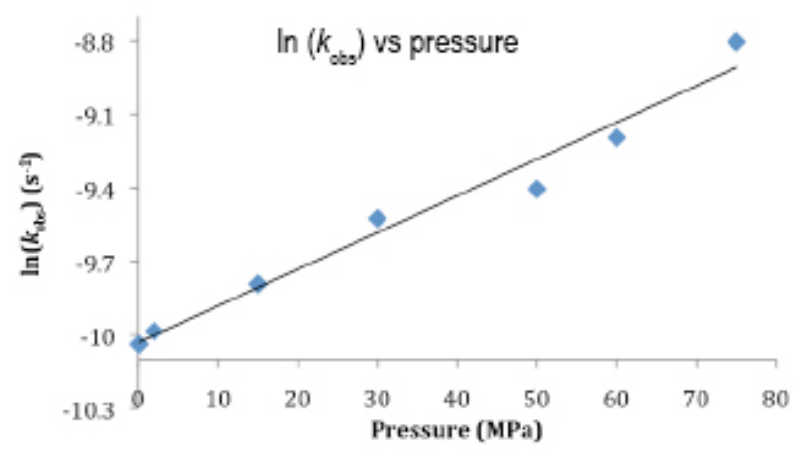

Figure 4. Pressure dependence curve; $\left[\mathrm{AsPh}_{3}\right]=0.116 \mathrm{M}, \mathrm{T}=288 \mathrm{~K}$.

\section{Conclusion}

The present studies have confirmed the unusual nature of the high-nuclearity cluster anion $\left[\mathrm{Ru}_{10}(\mu-\mathrm{H})\left(\mu_{6^{-}}\right.\right.$ $\left.\mathrm{C})(\mathrm{CO})_{24}\right]^{-}$, the limited reactivity studies from earlier reports being extended to further group 15 ligands; a diverse range of high-nuclearity clusters of varying levels of ligand substitution have been shown to be accessible under very mild conditions. The spectral data of the cluster anions is consistent with the possibility of tuning core electron density as a function of incoming ligand and extent of substitution. The cluster dianion $\left[\mathrm{Ru}_{10}\left(\mu_{6}-\mathrm{C}\right)(\mathrm{CO})_{24}\right]^{2-}$ has been shown to react with concomitant core oxidation, affording the structurally characterized neutral cluster $\mathrm{Ru}{ }_{10}\left(\mu_{6}-\mathrm{C}\right)\left(\mu_{3}-\mathrm{CO}\right)(\mu-\mathrm{CO})(\mathrm{CO}){ }_{19}\left(\mathrm{P}\left\{\mathrm{C}_{6} \mathrm{H}_{4} \mathrm{Me}-4\right)_{3}\right\}$. Kinetic studies of one example of ligand substitution in the decaruthenium hydrido anion system are consistent with a strongly associative pathway, intermediate species probably involving Ru-Ru cleavage. 


\section{Experimental}

All reactions were carried out under an atmosphere of nitrogen using Schlenk techniques. All solvents were used as received. Petroleum spirit refers to the petroleum fraction of boiling range $60-80{ }^{\circ} \mathrm{C}$. Reagents were obtained commercially and used as received. [PPh 4$]\left[\mathrm{Ru}_{10}(\mu-\mathrm{H})\left(\mu_{6}-\mathrm{C}\right)(\mathrm{CO})_{24}\right]$ and $\left[\mathrm{PPh}_{4}\right]_{2}\left[\mathrm{Ru}_{10}\left(\mu_{6}-\mathrm{C}\right)(\mathrm{CO})_{24}\right]$ were prepared according to the literature [8]. Cluster compounds were purified by preparative thin-layer chromatography (TLC) on $20 \times 20 \mathrm{~cm}$ glass plates coated with Merck $\mathrm{GF}_{254}$ silica gel $(0.5 \mathrm{~mm})$; no special precautions were taken to exclude air in their manipulation.

Infrared spectra were recorded in AR grade acetone solvent on a Perkin-Elmer System 2000 FT-IR spectrometer using a solution cell with $\mathrm{CaF}_{2}$ windows; spectral features are reported in $\mathrm{cm}^{-1} .{ }^{1} \mathrm{H}(300$ $\mathrm{MHz})$ and ${ }^{31} \mathrm{P}$ NMR (121 MHz) spectra were recorded on a Varian Gemini-300 spectrometer; spectra were recorded in $\mathrm{d}_{6}$-acetone and referenced to residual solvent peaks or external phosphoric acid. ESI mass spectra were recorded on a Micromass-Waters LC-ZMD single quadrupole liquid chromatographMS instrument at the Research School of Chemistry, Australian National University, and are reported in the form: $m / z$ (assignment). Microanalyses were carried out by the Microanalysis Service Unit in the Research School of Chemistry, ANU.

\subsection{Synthesis of $[\mathrm{PPh} 4]\left[\mathrm{Ru} 10(\mu-\mathrm{H})\left(\mu_{6}-\mathrm{C}\right)(\mathrm{CO})_{23}\left\{\mathrm{P}\left(\mathrm{C}_{6} \mathrm{H}_{4} \mathrm{Me}-4\right)_{3}\right\}\right](\mathbf{1 a})$.}

Tri(p-tolyl)phosphine $(2.5 \mathrm{mg}, 8.2 \mu \mathrm{mol})$ was added to a stirred dark-brown solution of $\left[\mathrm{PPh}_{4}\right]\left[\mathrm{Ru}_{10}(\mu\right.$ $\left.\mathrm{H})\left(\mu_{6}-\mathrm{C}\right)(\mathrm{CO})_{24}\right](17 \mathrm{mg}, 8.4 \mu \mathrm{mol})$ in acetone $(10 \mathrm{~mL})$. An IR spectrum immediately after addition showed complete reaction. The solution was taken to dryness in vacuo, and the crude residue dissolved in a minimum amount of acetone and applied to silica preparative TLC plates. Elution with acetone/petrol $(1: 1)$ afforded 2 bands. The contents of the first band $\left(\mathrm{R}_{f}=0.53\right.$, brown) were extracted with acetone and taken to dryness to afford a brown solid identified as unreacted starting cluster $\left[\mathrm{PPh}_{4}\right]\left[\mathrm{Ru}_{10}(\mu-\mathrm{H})\left(\mu_{6}-\right.\right.$ $\left.\mathrm{C})(\mathrm{CO})_{24}\right](1.2 \mathrm{mg}, 0.59 \mu \mathrm{mol}, 7 \%)$ by IR spectroscopy. The contents of the second and major band $\left(\mathrm{R}_{\mathrm{f}}=\right.$ 0.44, brown) were extracted with acetone, petroleum spirit was added, and the volume reduced to afford a brown solid identified as $\left[\mathrm{PPh}_{4}\right]\left[\mathrm{Ru} 10(\mu-\mathrm{H})\left(\mu_{6}-\mathrm{C}\right)(\mathrm{CO})_{23}\left\{\mathrm{P}\left(\mathrm{C}_{6} \mathrm{H}_{4} \mathrm{Me}-4\right)_{3}\right\}\right](\mathbf{1 a}, 16 \mathrm{mg}, 7.0 \mu \mathrm{mol}, 82 \%)$. IR (acetone): v(CO) $2076 \mathrm{w}, 2046 \mathrm{vs}, 2017 \mathrm{~s}, 2001 \mathrm{~s} \mathrm{~cm}^{-1} .{ }^{1} \mathrm{H}$ NMR (d6-acetone): $\delta 7.92$ - 7.19 (m, 32H, Ar-H), 2.39 (s, 9H, Me), -11.53 (d, $\left.J_{\mathrm{PH}}=7.2 \mathrm{~Hz}, 1 \mathrm{H}, \mathrm{Ru}-\mathrm{H}\right) .{ }^{31} \mathrm{P}$ NMR (d6-acetone): $\delta 42.0\left(\mathrm{P}\left(\mathrm{C}_{6} \mathrm{H}_{4} \mathrm{Me}-\right.\right.$ 4) $\left.)_{3}\right), 24.0\left(\mathrm{PPh}_{4}\right)$. MS (ESI): $1972\left([\mathrm{M}]^{-}\right)$. Analysis: Calc for $\mathrm{C}_{69} \mathrm{H}_{42} \mathrm{O}_{23} \mathrm{P}_{2} \mathrm{Ru}_{10}$ : C 35.85, H 1.83\%; found C $35.53, \mathrm{H} 1.67 \%$.

4.2. Synthesis of $\left[P P h_{4}\right]\left[R u_{10}(\mu-H)\left(\mu_{6}-C\right)(C O)_{22}\left\{P\left(C_{6} H_{4} M e-4\right)_{3}\right\}_{2}\right]$ (2a) and $\left[P P h_{4}\right]\left[R u_{10}\left(\mu_{-} H\right)\left(\mu_{6^{-}}\right.\right.$ C) $\left.\left.(\mathrm{CO})_{21}\left\{\mathrm{P}\left(\mathrm{C}_{6} \mathrm{H}_{4} \mathrm{Me}-4\right)_{3}\right\}_{3}\right] \mathbf{( 3 a}\right)$. 
Tri(p-tolyl)phosphine $(9.6 \mathrm{mg}, 32 \mu \mathrm{mol})$ was added to a dark-brown solution of $\left[\mathrm{PPh}_{4}\right]\left[\mathrm{Ru}_{10}(\mu-\mathrm{H})\left(\mu_{6^{-}}\right.\right.$ $\left.\mathrm{C})(\mathrm{CO})_{24}\right](27 \mathrm{mg}, 13 \mu \mathrm{mol})$ in acetone $(10 \mathrm{~mL})$ and the resultant mixture stirred for $2 \mathrm{~h}$, at which time an IR spectrum showed that the reaction was complete. The solution was taken to dryness in vacuo, and the crude residue dissolved in a minimum amount of acetone and applied to silica preparative TLC plates. Elution with acetone/petrol (1:1) afforded 2 bands. The contents of the first band $\left(\mathrm{R}_{\mathrm{f}}=0.45\right.$, brown) were extracted with acetone, petroleum spirit was added, and the volume was reduced, to afford a brown solid identified as $\left[\mathrm{PPh}_{4}\right]\left[\mathrm{Ru}{ }_{10}(\mu-\mathrm{H})\left(\mu_{6}-\mathrm{C}\right)(\mathrm{CO})_{22}\left\{\mathrm{P}\left(\mathrm{C}_{6} \mathrm{H}_{4} \mathrm{Me}-4\right)_{3}\right\}_{2}\right](2,19 \mathrm{mg}, 7.2 \mu \mathrm{mol}, 54 \%)$. IR (acetone): v(CO) $2062 \mathrm{w}, 2038 \mathrm{~s}, 2011 \mathrm{~s} \mathrm{sh}, 2007 \mathrm{vs}, 1991 \mathrm{~m} \mathrm{sh} \mathrm{cm}^{-1} .{ }^{1} \mathrm{H}$ NMR (d6-acetone): $\delta 7.92$ - 7.19 (m, 44H, Ar-H), 2.39 (s, 18H, Me), -11.49 (d, JPH $=7.2 \mathrm{~Hz}, 1 \mathrm{H}, \mathrm{Ru}-\mathrm{H}) .{ }^{31} \mathrm{P}$ NMR (d6-acetone): $\delta 49.8\left(\mathrm{P}\left(\mathrm{C}_{6} \mathrm{H}_{4} \mathrm{Me}-\right.\right.$ 4)3), $41.0\left(\mathrm{P}_{\mathrm{RuH}}\left(\mathrm{C}_{6} \mathrm{H}_{4} \mathrm{Me}-4\right)_{3}\right), 24.0\left(\mathrm{PPh}_{4}\right)$. MS (ESI): 2248 ([M] $]^{-}$). Analysis: Calc for $\mathrm{C}_{89} \mathrm{H}_{63} \mathrm{O}_{22} \mathrm{P}_{3} \mathrm{Ru}_{10}$ : C 41.30, H 2.45\%; found C 41.07, H 2.29\%. The contents of the second band $\left(\mathrm{R}_{\mathrm{f}}=0.38\right.$, brown) were extracted with acetone, petroleum spirit was added, and the volume was reduced, to afford a brown solid, identified as $\left[\mathrm{PPh}_{4}\right]\left[\mathrm{Ru}_{10}(\mu-\mathrm{H})\left(\mu_{6}-\mathrm{C}\right)(\mathrm{CO})_{21}\left\{\mathrm{P}\left(\mathrm{C}_{6} \mathrm{H}_{4} \mathrm{Me}-4\right)_{3}\right\}_{3}\right](3,10 \mathrm{mg}, 3.6 \mu \mathrm{mol}, 27 \%)$. IR (acetone): v(CO) 2046 w, $2011 \mathrm{~m}, 1998 \mathrm{vs} \mathrm{cm}^{-1} .{ }^{1} \mathrm{H}$ NMR (d6-acetone): $\delta 7.92-7.19$ (m, 56H, Ar-H), 2.39 (s, 27H,

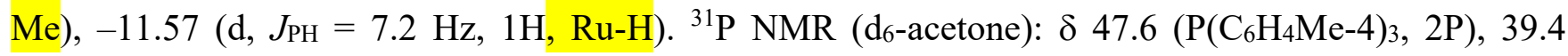
$\left(\mathrm{P}_{\mathrm{RuH}}\left(\mathrm{C}_{6} \mathrm{H}_{4} \mathrm{Me}-4\right) 3,1 \mathrm{P}\right), 24.0\left(\mathrm{PPh}_{4}\right)$. MS (ESI): $2525\left([\mathrm{M}]^{-}\right)$. Analysis: Calc for $\mathrm{C}_{109} \mathrm{H}_{84} \mathrm{O}_{21} \mathrm{P}_{4} \mathrm{Ru}_{10}: \mathrm{C}$ 45.71, H 2.96\%; found C 45.43, H 2.76\%.

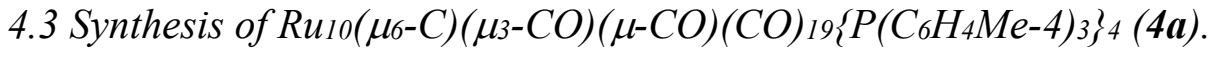

Tri(p-tolyl)phosphine $(46.0 \mathrm{mg}, 151 \mu \mathrm{mol})$ was added to a stirred dark-green solution of $\left[\mathrm{PPh}_{4}\right]_{2}\left[\mathrm{Ru}_{10}\left(\mu_{6}-\mathrm{C}\right)(\mathrm{CO})_{24}\right](22.9 \mathrm{mg}, 9.65 \mu \mathrm{mol})$ in acetone $(10 \mathrm{~mL})$, an IR spectrum on addition showing complete reaction. The solution was taken to dryness in vacuo, and the crude residue dissolved in the minimum amount of acetone and applied to silica preparative TLC plates. Elution with acetone/petrol (2:3) afforded 2 bands. The contents of the second band $\left(\mathrm{R}_{f}=0.48\right.$, brown $)$ appeared to be in trace amounts and were not isolated. The contents of the first and major band $\left(\mathrm{R}_{\mathrm{f}}=0.55\right.$, brown) were extracted with acetone and reduced in volume to afford a brown solid identified as $\mathrm{Ru} u_{10}\left(\mu_{6}-\mathrm{C}\right)\left(\mu_{3}-\mathrm{CO}\right)(\mu-$ $\mathrm{CO})(\mathrm{CO})_{19}\left\{\mathrm{P}\left(\mathrm{C}_{6} \mathrm{H}_{4} \mathrm{Me}-4\right)_{3}\right\}_{4}(4 \mathbf{a}, 25.7 \mathrm{mg}, 9.09 \mu \mathrm{mol}, 94 \%)$. Diffusion of propan-2-ol into a solution of 4a in $\mathrm{CH}_{2} \mathrm{Cl}_{2}$ at $-20{ }^{\circ} \mathrm{C}$ gave dark brown crystals. IR $\left(\mathrm{CH}_{2} \mathrm{Cl}_{2}\right)$ : v(CO) $2042 \mathrm{w}, 2019 \mathrm{vs}, 1985 \mathrm{~m}, 1714 \mathrm{w}$ br cm ${ }^{-1} .{ }^{1} \mathrm{H}$ NMR (d6-acetone): $\delta 7.52$ - 7.25 (m, 48H, Ar-H), 2.41 (s, 36H, Me). ${ }^{31} \mathrm{P}$ NMR (d6-acetone): $\delta 44.5\left(\mathrm{P}\left(\mathrm{C}_{6} \mathrm{H}_{4} \mathrm{Me}\right)_{3}\right)$. MS (ESI): $2851\left([\mathrm{M}+\mathrm{Na}]^{+}, 100\right)$. Analysis: Calc for $\mathrm{C}_{106} \mathrm{H}_{84} \mathrm{O}_{21} \mathrm{P}_{4} \mathrm{Ru}_{10}$ : C 35.73, H 2.99\%; found C 35.36, H 2.87\%.

\subsection{Synthesis of $\left[P P_{4}\right]\left[R u_{10}(\mu-H)\left(\mu_{6}-C\right)\left(A s P h_{3}\right)(C O)_{23}\right](\mathbf{1 b})$.}

Triphenylarsine $(3.9 \mathrm{mg}, 13 \mu \mathrm{mol})$ was added to a stirred dark-brown solution of $\left[\mathrm{PPh}_{4}\right]\left[\mathrm{Ru}_{10}(\mu-\mathrm{H})\left(\mu_{6}{ }^{-}\right.\right.$ $\left.\mathrm{C})(\mathrm{CO})_{24}\right](26 \mathrm{mg}, 13 \mu \mathrm{mol})$ in acetone $(10 \mathrm{~mL})$. An IR spectrum immediately after addition showed 
complete reaction. The solution was taken to dryness in vacuo, and the crude residue dissolved in a minimum amount of acetone and applied to silica preparative TLC plates. Elution with acetone/petrol (1:1) afforded 3 bands. The contents of the first band $\left(\mathrm{R}_{f}=0.53\right.$, brown) were extracted with acetone and taken to dryness to afford a brown solid identified as unreacted starting cluster $\left[\mathrm{PPh}_{4}\right]\left[\mathrm{Ru}_{10}(\mu-\mathrm{H})\left(\mu_{6^{-}}\right.\right.$ $\left.\mathrm{C})(\mathrm{CO})_{24}\right](0.9 \mathrm{mg}, 0.4 \mu \mathrm{mol}, 3 \%)$ by IR spectroscopy. The contents of the third band $\left(\mathrm{R}_{f}=0.33\right.$, brown $)$ were extracted with acetone and taken to dryness to afford a brown solid identified as $\left[\mathrm{PPh}_{4}\right]\left[\mathrm{Ru}_{10}(\mu-\right.$ $\left.\mathrm{H})\left(\mu_{6}-\mathrm{C}\right)(\mathrm{CO})_{22}\left(\mathrm{AsPh}_{3}\right)_{2}\right](\mathbf{2 b}, 3.6 \mathrm{mg}, 1.4 \mu \mathrm{mol}, 11 \%$; see below $)$. The contents of the second and major band $\left(R_{\mathrm{f}}=0.40\right.$, brown $)$ were extracted with acetone, petroleum spirit was added, and the volume was reduced, to afford a brown solid, identified as $\left[\mathrm{PPh}_{4}\right]\left[\mathrm{Ru} 10(\mu-\mathrm{H})\left(\mu_{6}-\mathrm{C}\right)\left(\mathrm{AsPh}_{3}\right)(\mathrm{CO})_{23}\right](\mathbf{1 b}, 23 \mathrm{mg}, 10$ $\mu \mathrm{mol}, 77 \%)$. IR (acetone): v(CO, cluster) $2078 \mathrm{w}, 2048 \mathrm{vs}, 2017 \mathrm{~s}, 2002 \mathrm{~s} \mathrm{~cm}^{-1} .{ }^{1} \mathrm{H}$ NMR (d6-acetone): $\delta$ $7.92-7.19$ (m, 35H, Ar-H), -11.81 (s, 1H, Ru-H). ${ }^{31} \mathrm{P}$ NMR (d6-acetone): $\delta 24.0\left(\mathrm{PPh}_{4}\right) . \mathrm{MS}$ (ESI): 1974

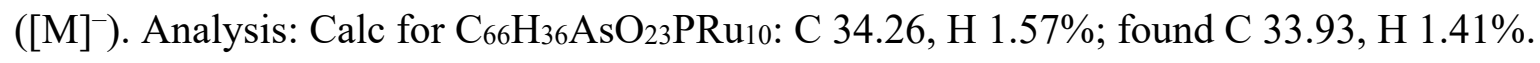

\subsection{Synthesis of $\left[P P_{4}\right]\left[R u_{10}(\mu-H)\left(\mu_{6-C} C\left(A s h_{3}\right)_{2}(C O)_{22}\right] \quad\right.$ (2b) and $\left[P P h_{4}\right]\left[R u_{10}(\mu-H)\left(\mu_{6^{-}}\right.\right.$ C) $\left.\left(\mathrm{AsPh}_{3}\right)_{3}(\mathrm{CO})_{21}\right](\mathbf{3 b})$.}

Triphenylarsine $(7.5 \mathrm{mg}, 25 \mu \mathrm{mol})$ was added to a dark-brown solution of $\left[\mathrm{PPh}_{4}\right]\left[\mathrm{Ru}_{10}(\mu-\mathrm{H})\left(\mu_{6}-\right.\right.$ $\left.\mathrm{C})(\mathrm{CO})_{24}\right](22 \mathrm{mg}, 11 \mu \mathrm{mol})$ in acetone $(10 \mathrm{~mL})$ and the resultant mixture stirred for $72 \mathrm{~h}$, after which an IR spectrum showed that the reaction was complete. The solution was taken to dryness in vacuo, and the crude residue dissolved in a minimum amount of acetone and applied to silica preparative TLC plates. Elution with acetone/petrol (1:1) afforded 2 bands. The contents of the first band $\left(\mathrm{R}_{\mathrm{f}}=0.33\right.$, brown $)$ were extracted with acetone, petroleum spirit was added, and the volume was reduced, to afford a brown solid identified as $\left[\mathrm{PPh}_{4}\right]\left[\mathrm{Ru}_{10}(\mu-\mathrm{H})\left(\mu_{6}-\mathrm{C}\right)\left(\mathrm{AsPh}_{3}\right)_{2}(\mathrm{CO})_{22}\right](\mathbf{2 b}, 13 \mathrm{mg}, 4.9 \mu \mathrm{mol}, 46 \%)$. IR (acetone): $v(\mathrm{CO})$ 2065 w, 2041 s, 2012 s sh, 2008 vs, $1993 \mathrm{~m} \mathrm{sh} \mathrm{cm}^{-1}$. ${ }^{1} \mathrm{H}$ NMR (d6-acetone): $\delta 7.92-7.19$ (m, 50H, Ar$\mathrm{H}),-11.71$ (s, 1H, Ru-H). ${ }^{31} \mathrm{P}$ NMR (d6-acetone): $\delta 24.0\left(\mathrm{PPh}_{4}\right)$. MS (ESI): $2252\left([\mathrm{M}]^{-}\right)$. Analysis: Calc for $\mathrm{C}_{83} \mathrm{H}_{51} \mathrm{As}_{2} \mathrm{O}_{22} \mathrm{PRu} 10$ : C 38.46, H 1.98\%; found C 38.12, H 1.73\%. The contents of the second band $\left(\mathrm{R}_{\mathrm{f}}\right.$ $=0.27$, brown) were extracted with acetone, petroleum spirit was added, and the volume was reduced, to afford a brown solid identified as $\left[\mathrm{PPh}_{4}\right]\left[\mathrm{Ru} 10(\mu-\mathrm{H})\left(\mu_{6}-\mathrm{C}\right)\left(\mathrm{AsPh}_{3}\right)_{3}(\mathrm{CO})_{21}\right](\mathbf{3 b}, 7.9 \mathrm{mg}, 2.8 \mu \mathrm{mol}, 26 \%)$. IR (acetone): v(CO) 2050 w, 2013 m, $2000 \mathrm{vs} \mathrm{cm}^{-1} .{ }^{1} \mathrm{H}$ NMR (d6-acetone): $\delta 7.92-7.19$ (m, 65H, Ar-H), -11.68 (s, 1H, Ru-H). ${ }^{31} \mathrm{P}$ NMR (d6-acetone): $\delta 24.0\left(\mathrm{PPh}_{4}\right)$. MS (ESI): $2531\left([\mathrm{M}]^{-}\right)$. Analysis: Calc for $\mathrm{C}_{100} \mathrm{H}_{66} \mathrm{Ass}_{3} \mathrm{O}_{21} \mathrm{PRu} 10$ : C 41.85, H 2.32\%; found C 41.36, H 2.01\%.

\subsection{Synthesis of $\left[\mathrm{PPh}_{4}\right]\left[\mathrm{Ru} 10(\mu-H)\left(\mu_{6}-\mathrm{C}\right)(\mathrm{CO})_{23}\left(\mathrm{SbPh}_{3}\right)\right](\mathbf{1 c})$.}

Triphenylstibine $(2.4 \mathrm{mg}, 6.8 \mu \mathrm{mol})$ was added to a stirred dark-brown solution of $\left[\mathrm{PPh}_{4}\right]\left[\mathrm{Ru}_{10}(\mu-\mathrm{H})\left(\mu_{6^{-}}\right.\right.$ $\left.\mathrm{C})(\mathrm{CO})_{24}\right](10 \mathrm{mg}, 5.1 \mu \mathrm{mol})$ in acetone $(10 \mathrm{~mL})$. An IR spectrum immediately after addition showed complete reaction. The solution was taken to dryness in vacuo, and the crude residue dissolved in a 
minimum amount of acetone and applied to silica preparative TLC plates. Elution with acetone/petrol (1:1) afforded 3 bands. The contents of the first band $\left(\mathrm{R}_{f}=0.51\right.$, brown) were extracted with acetone and taken to dryness to afford a brown solid identified as the starting cluster $\left[\mathrm{PPh}_{4}\right]\left[\mathrm{Ru}_{10}(\mu-\mathrm{H})\left(\mu_{6}-\mathrm{C}\right)(\mathrm{CO})_{24}\right]$ ( $1.4 \mathrm{mg}, 0.69 \mu \mathrm{mol}, 13 \%)$ by IR spectroscopy. The contents of the third band $\left(\mathrm{R}_{f}=0.29\right.$, brown) were extracted with acetone and taken to dryness to afford a brown solid identified as $\left[\mathrm{PPh}_{4}\right]\left[\mathrm{Ru}_{10}(\mu-\mathrm{H})\left(\mu_{6^{-}}\right.\right.$ $\left.\mathrm{C})(\mathrm{CO})_{22}\left(\mathrm{SbPh}_{3}\right)_{2}\right]$ (2c, $1.0 \mathrm{mg}, 0.37 \mu \mathrm{mol}, 7 \%$, see below). The contents of the second and major band $\left(\mathrm{R}_{\mathrm{f}}=0.37\right.$, brown $)$ were extracted with acetone, petroleum spirit was added, and the volume was reduced, to afford a brown solid identified as $\left[\mathrm{PPh}_{4}\right]\left[\mathrm{Ru}_{10}(\mu-\mathrm{H})\left(\mu_{6}-\mathrm{C}\right)(\mathrm{CO})_{23}\left(\mathrm{SbPh}_{3}\right)\right](\mathbf{1 c}, 6.7 \mathrm{mg}, 2.8 \mu \mathrm{mol}, 56 \%)$. IR (acetone): v(CO) 2078 w, 2048 vs, 2016 s, $2003 \mathrm{~s} \mathrm{~cm}^{-1} .{ }^{1} \mathrm{H}$ NMR (d6-acetone): $\delta 7.92-7.19$ (m, 35H, Ar-H), -12.36 (s, 1H, Ru-H). ${ }^{31} \mathrm{P}$ NMR (d6-acetone): $\delta 24.0$ (PPh4). MS (ESI): $2020\left([\mathrm{M}]^{-}\right)$. Analysis: Calc for $\mathrm{C}_{66} \mathrm{H}_{36} \mathrm{O}_{23} \mathrm{PRu} 10 \mathrm{Sb}$ : C 33.58, $\mathrm{H} \mathrm{1.54 \%}$; found C 33.02, H 1.17\%.

\subsection{Synthesis of $\left[P P h_{4}\right]\left[R u_{10}(\mu-H)\left(\mu_{6-C}\right)(C O)_{22}\left(S_{b P h}\right)_{2}\right] \quad$ (2c) and $\left[P P h_{4}\right]\left[R u_{10}(\mu-H)\left(\mu_{6-}\right.\right.$ C) $\left.(\mathrm{CO})_{21}\left(\mathrm{SbPh}_{3}\right)_{3}\right](\mathbf{3 c})$.}

Triphenylstibine $(10.7 \mathrm{mg}, 30.3 \mu \mathrm{mol})$ was added to a dark-brown solution of $\left[\mathrm{PPh}_{4}\right]\left[\mathrm{Ru}_{10}(\mu-\mathrm{H})\left(\mu_{6^{-}}\right.\right.$ $\left.\mathrm{C})(\mathrm{CO})_{24}\right](21.6 \mathrm{mg}, 10.6 \mu \mathrm{mol})$ in acetone $(10 \mathrm{~mL})$ and the resultant mixture stirred for $72 \mathrm{~h}$, after which an IR spectrum showed that the reaction was complete. The solution was taken to dryness in vacuo, and the crude residue dissolved in a minimum amount of acetone and applied to preparative silica TLC plates. Elution with acetone/petrol (1:1) afforded 2 bands. The contents of the first band $\left(\mathrm{R}_{\mathrm{f}}=0.29\right.$, brown $)$ were extracted with acetone, petroleum spirit was added, and the volume reduced, to afford a brown solid identified as $\left[\mathrm{PPh}_{4}\right]\left[\mathrm{Ru}_{10}(\mu-\mathrm{H})\left(\mu_{6}-\mathrm{C}\right)(\mathrm{CO})_{22}\left(\mathrm{SbPh}_{3}\right)_{2}\right](\mathbf{2 c}, 8.1 \mathrm{mg}, 3.0 \mu \mathrm{mol}, 28 \%)$. IR (acetone): $v(\mathrm{CO})$ 2066 w, 2042 s, 2011 s sh, 2007 vs, $1993 \mathrm{~m} \mathrm{sh} \mathrm{cm}^{-1}$. ${ }^{1} \mathrm{H}$ NMR (d6-acetone): $\delta 7.92$ - 7.19 (m, 50H, Ar$\mathrm{H}),-12.26$ (s, 1H, Ru-H). ${ }^{31} \mathrm{P}$ NMR (d6-acetone): $\delta 24.0\left(\mathrm{PPh}_{4}\right) . \mathrm{MS}(\mathrm{ESI}): 2345\left([\mathrm{M}]^{-}\right)$. Analysis: Calc for $\mathrm{C}_{83} \mathrm{H}_{51} \mathrm{O}_{22} \mathrm{PRu}_{10} \mathrm{Sb}_{2}$ : C 37.12, H 1.91\%; found C 36.43, H 1.52\%. The contents of the second band $\left(\mathrm{R}_{\mathrm{f}}\right.$ $=0.23$, brown) were extracted with acetone, petroleum spirit was added, and the volume was reduced, to afford a brown solid identified as $\left[\mathrm{PPh}_{4}\right]\left[\mathrm{Ru}_{10}(\mu-\mathrm{H})\left(\mu_{6}-\mathrm{C}\right)(\mathrm{CO})_{21}\left(\mathrm{SbPh}_{3}\right)_{3}\right](\mathbf{3 c}, 7.3 \mathrm{mg}, 2.4 \mu \mathrm{mol}, 23 \%)$. IR (acetone): v(CO) $2051 \mathrm{w}, 2013 \mathrm{~m}, 2000 \mathrm{vs} \mathrm{cm}^{-1} .{ }^{1} \mathrm{H}$ NMR (d6-acetone): $\delta 7.92-7.19$ (m, 65H, Ar-H), -12.21 (s, 1H, Ru-H). ${ }^{31} \mathrm{P}$ NMR (d6-acetone): $\delta 24.0\left(\mathrm{PPh}_{4}\right)$. MS (ESI): $2672\left([\mathrm{M}]^{-}\right)$. Analysis: Calc for $\mathrm{C}_{100} \mathrm{H}_{66} \mathrm{O}_{21} \mathrm{PRu}_{10} \mathrm{Sb}_{3}$ : C 39.90, H 2.21\%; found C 39.16, H 1.89\%.

\subsection{X-ray crystallographic study}

Crystals of $\mathrm{Ru}_{10}\left(\mu_{6}-\mathrm{C}\right)\left(\mu_{3}-\mathrm{CO}\right)(\mu-\mathrm{CO})(\mathrm{CO})_{19}\left(\mathrm{P}\left\{\mathrm{C}_{6} \mathrm{H}_{4} \mathrm{Me}-4\right)_{3}\right\}_{4}(\mathbf{4 a})$ suitable for the X-ray structural analysis were grown by liquid diffusion of propan-2-ol into a dichloromethane solution at $277 \mathrm{~K}$. Intensity data were collected with an Enraf-Nonius KAPPA CCD diffractometer at $200 \mathrm{~K}$ using Mo- $K_{\alpha}$ radiation $(\lambda=0.7170 \AA)$. A suitable crystal was immersed in viscous hydrocarbon oil and mounted on a glass fiber 
that was mounted on the diffractometer. Using $\psi$ and $\omega$ scans, $N_{\mathrm{t}}$ (total) reflections were measured, which were reduced to $N_{\mathrm{o}}$ unique reflections, with $F_{\mathrm{o}}>2 \sigma\left(F_{\mathrm{o}}\right)$ being considered "observed". The crystal was face-indexed, and a Gaussian grid absorption correction was applied [16]. Data were initially processed using the programs DENZO and Scalepack [17]. The structure was solved by direct methods, and observed reflections were used in least-squares refinement on $F^{2}$, with anisotropic thermal parameters refined for non-hydrogen atoms. Hydrogen atoms were constrained in calculated positions and refined with a riding model. The structure solution and refinements were performed by using the programs SHELXS-97 [18] and SHELXL-2014 [19] through the graphical interface Olex2 [20], which was also used to generate the figures.

Crystal Data for Ru10 $\left(\mu_{6}-C\right)\left(\mu_{3}-C O\right)(\mu-C O)(C O)_{19}\left(P\left\{C_{6} H_{4} M e-4\right)_{3}\right\}_{4}: \mathrm{C}_{106} \mathrm{H}_{84} \mathrm{O}_{21} \mathrm{P}_{4} \mathrm{Ru}_{10}, M=2828.31$, brown prism, $0.39 \times 0.02 \times 0.02 \mathrm{~mm}$, triclinic, space group $P-1$ (no. 2), $a=17.5864(6), b=18.1211(7), c$ $=22.5149(9) \AA, \alpha=113.507(2), \beta=93.852(2), \gamma=93.098(2)^{\circ}, V=6539.2(4) \AA^{3}, Z=2, D_{\mathrm{c}}=1.436$ $\mathrm{g} / \mathrm{cm}^{3}, F(000)=2776.0, \mu=1.223 \mathrm{~mm}^{-1}, 2 \theta_{\max }=45.3^{\circ}, 87421$ reflections collected, 17310 unique. Final $G o F=0.941, R 1=0.0617, w R 2=0.1526, R$ indices based on 10047 reflections with $I>2 \sigma(I)$ refinement on $F^{2}$ ), 1282 parameters, 0 restraints. Variata: The crystal diffracted weakly; no diffraction was evident above $22.5^{\circ}$, even with long exposure times. Attempts to grow better quality crystals were unsuccessful. Severely disordered lattice solvent molecules could not be successfully modelled and were therefore removed from the refinement using the smtbx-masks function of Olex2 [20]. The crystals were dried under vacuum prior to spectroscopic and elemental analyses, resulting in the loss of lattice solvent, so we are unable to identify the solvent molecules. The largest peaks in the final difference electron density map are located near the ruthenium atoms.

\subsection{Kinetic measurements}

Kinetic measurements were performed at the University of Erlangen-Nuremberg, Germany, on a widebore $400 \mathrm{MHz}$ Bruker NMR instrument at ambient and hydrostatic pressure [21,22]. The high-pressure probe was tuned for ${ }^{1} \mathrm{H}-\mathrm{NMR}$ and tested for pressures up to $200 \mathrm{MPa}$. The significant pressure acceleration observed for the studied reaction did not require measurements at pressures higher than 80 MPa.

\section{Acknowledgments}

We thank the Australian Research Council (ARC) for financial support. M.D.R. was the recipient of an Australian Postgraduate Award. 


\section{Supplementary data}

CCDC 1529616 contains the supplementary crystallographic data for this paper. The data can be obtained free of charge from The Cambridge Crystallographic Data Centre via www.ccdc.cam.ac.uk/structures.

\section{References}

[1] D.F. Shriver, H.D. Kaesz, R.D. Adams, The Chemistry of Metal Cluster Complexes, V.C.H., New York, 1990.

[2] M.P. Cifuentes, M.G. Humphrey, B.W. Skelton, A.H. White, Organometallics 12 (1993) 4272.

[3] R.E. Benfield, P.P. Edwards, A.M. Stacy, J. Chem. Soc., Chem. Commun. (1982) 525.

[4] D.C. Johnson, R.E. Benfield, P.P. Edwards, W.J.H. Nelson, M.D. Vargas, Nature 314 (1985) 231.

[5] M.P. Cifuentes, M.G. Humphrey, J.E. McGrady, P.J. Smith, R. Stranger, K.S. Murray, B. Moubaraki, J. Am. Chem. Soc. 119 (1997) 2647.

[6] M.P. Cifuentes, M.G. Humphrey, B.W. Skelton, A.H. White, Organometallics 14 (1995) 1536.

[7] M.P. Cifuentes, M.G. Humphrey, A.C. Willis, J. Organomet. Chem. 513 (1996) 85.

[8] M.P. Cifuentes, M.G. Humphrey, B.W. Skelton, A.H. White, J. Organomet. Chem. 507 (1996) 163.

[9] R.J. Goudsmit, P.F. Jackson, B.F.G. Johnson, J. Lewis, W.J.H. Nelson, J. Puga, M.D. Vargas, D. Braga, K. Henrick, M. McPartlin, A. Sironi, J. Chem. Soc., Dalton Trans. (1985) 1795.

[10] M.I. Bruce, M.G. Humphrey, M.R. Snow, E.R.T. Tiekink, R.C. Wallis, J. Organomet. Chem. 314 (1986) 311.

[11] R.J. Klinger, W.M. Butler, M.D. Curtis, J. Am. Chem. Soc. 100 (1978) 5034.

[12] A. Poe, M.V. Twigg, J. Chem. Soc., Dalton Trans. 17 (1974) 1860.

[13] R.H.E. Hudson, A.J. Poe, Inorg. Chim. Acta 259 (1997) 257.

[14] D.H. Farrar, A.J. Poë, Y. Zheng, J. Am. Chem. Soc. 116 (1994) 6252.

[15] A.J. Poë, D.H. Farrar, Y. Zheng, J. Am. Chem. Soc. 114 (1992) 5146.

[16] P. Coppens, in: F.R. Ahmed, S.R. Hall, C.P. Huber (Eds.), Crystallographic Computing, Munksgaard, Copenhagen, 1970, p. 225.

[17] Z. Otwinowski, W. Minor, in: C.W. Carter Jr, R.M. Sweet (Eds.), Methods in Enzymology, Academic Press, New York, 1997, p. 307.

[18] G.M. Sheldrick, Acta Crystallogr. A 64 (2008) 112.

[19] G.M. Sheldrick, Acta Crystallogr. A 71 (2015) 3.

[20] O.V. Dolomanov, L.J. Bourhis, R.J. Gildea, J.A.K. Howard, H. Puschmann, J. Appl. Crystallogr. 42 (2009) 339.

[21] A. Zahl, A. Neubrand, S. Aygen, R. van Eldik, Rev. Sci. Instrum. 65 (1994) 882.

[22] A. Zahl, P. Ingel, M. Weller, R. van Eldik, Rev. Sci. Instrum. 75 (2004) 3152. 